\title{
Towards a New Paradigm in City Branding and Marketing
}

\author{
The Case of Doha, Qatar \\ Ali ALRAOUF, Prof. of Architecture and Urbanism \\ CB, Research \& Development Coordinator \\ Urban Planning Department; Qatar
}

\begin{abstract}
In rentier countries around the Gulf, a paradigm shift is certainly happening. Gulf States resorted to branding strategies which would secure a global recognition for their cities. The paper analyzes the effectiveness of tools used in Doha, the capital city of Qatar to create its own identity within the Gulf States and the rest of the Middle East. The analyzed tools will include City Uniqueness, Quality of Public Spaces, Signature Architecture, Events, Festivals, Cultural Tourism and Facilities. One of the main strategies used in Doha to articulate its brand is enhancing the ability of the city to host global Events, Festivals, and international sports. Competitions and cultural Carnivals. The research illustrates the use of Interesting Architecture, Cultural Facilities, Unique streets, Public parks, City natural and man-made Uniqueness as a City Marketing and Positive Branding Tools. The paper investigates crucial questions including the impact of the digital paradigm on the competitiveness of cities? How to regionally and globally market a city? What are the sustainable and resilient strategies for branding contemporary city? The paper also articulates a model for the case of Doha city banding and marketing which is based on a balanced approach. Such an approach would consider traditional assets including history and heritage. Also, it will include contemporary and innovative assets resulted from the last decade unprecedented investments in the sectors of education, research, culture and knowledge. Hence, the paper suggests a more holistic approach to city branding which would balance between social equity, economic prospertiy and ecological intergrity.
\end{abstract}

\section{Keywords}

Place-branding, Doha's Urbanism, City Marketing and Branding, Post Carbon Urbanity, City as a Destination.

\section{The Contemporary Context of Gulf Cities}

\subsection{The Evolution of Oil-based Urbanism}

Once just sleepy desert settlements, the Arab Gulf states of Saudi Arabia, Oman, the United Arab Emirates, Qatar, Bahrain, and Kuwait now exert unprecedented influence on international affairs; the result of their almost unimaginable riches in oil and gas. Miller (2016) provides an account of the achievements of these countries since the 1973 global oil 
crisis. In the 1970s, one of the most hot and harsh regions in the world burst on to the international stage. The discovery and subsequent exploitation of oil allowed tribal rulers of the Gulf to dream big (Cooke, 2014). The unprecedented financial revenues substantially helped simple nomads, fishermen and pearl divers to catch up with the rest of the modernized world. Cooke also investigates how the shrewd Arab Gulf rulers who have overcome crisis after crisis meet the external and internal challenges of the onrushing future. In the last decade, the Arab Gulf region has become an East-West hub for travel, tourism, sport, culture, trade, and finance. But can the autocratic regimes maintain stability at home and influence abroad as they deal with the demands of social and democratic reform? Miller (2016) considers an array of factors-Islamism, terrorism, the Arab Spring, volatile oil prices, global power dynamics, and others-to assess the future possibilities. The entire Gulf cities are in the process of diversifying their economic base, with the vision of transitioning to a sustainable post-oil future. They are positioning themselves as places to visit, work and live. Place-branding has emerged as a significant trend across the Gulf cities in the construction of this image and consequently in the production of places. For a long number of years, the concepts of branding and marketing were thought of as notions only related to trade and commercial products. In the last two decades and as a reaction to the globalization paradigm, these concepts became City Branding. Among a rising competition between cities to attract the emerging creative and knowledge class and to capture a share in the global tourism, branding is now a major strategy adopted by many cities around the world to emphasize its unique character and personality. As defined in marketing theories, Branding is not about getting your target market to choose you over the competition, but it is about getting your prospects to see you as the only one that provides a solution to their problem. 


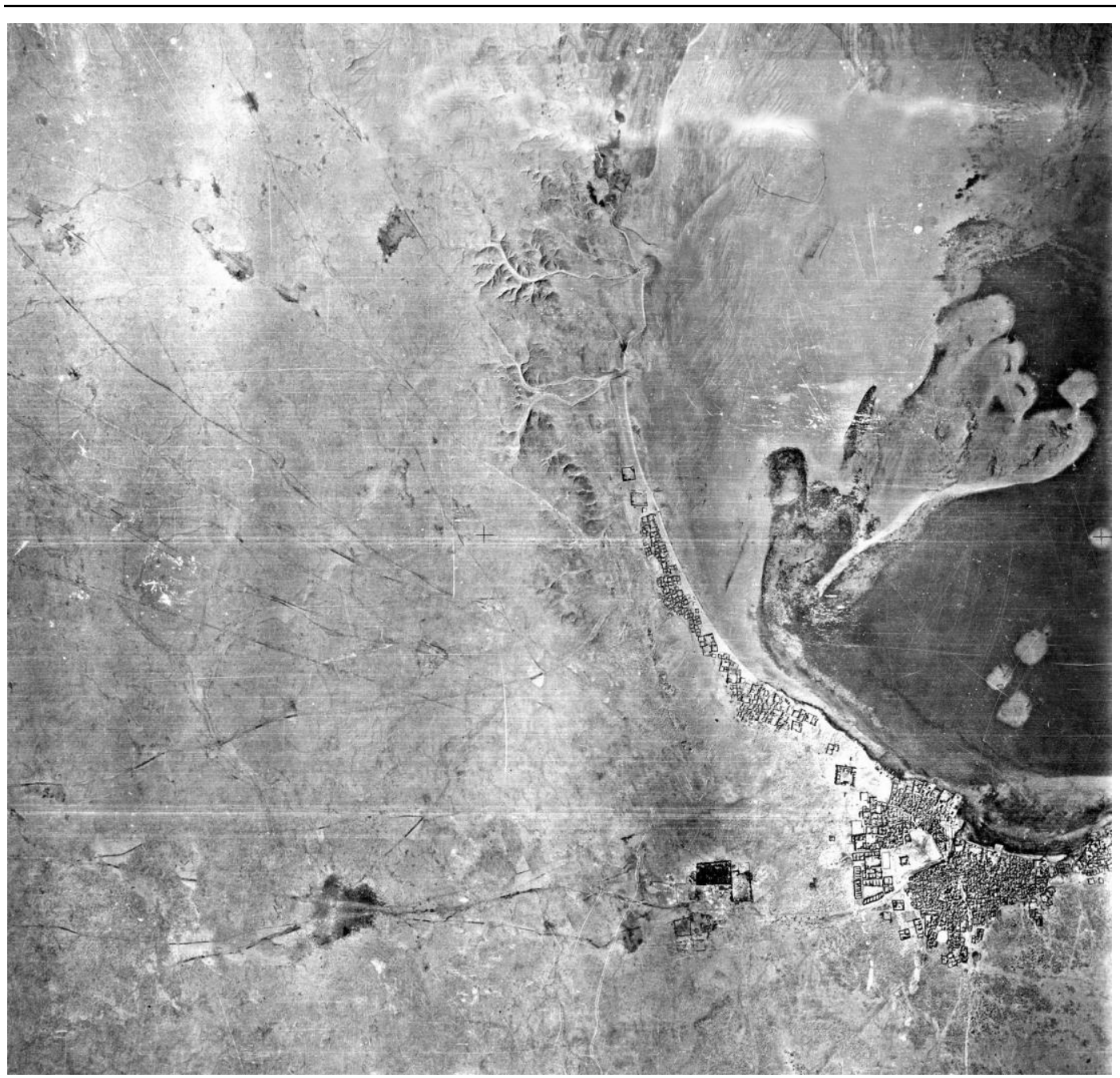

Figure 1 The Origin of Doha as a Traditional Settlement along the GUIf

The strategies used Gulf cities to transform itself into global destinations, were based on three consecutive cycles of development. The first is the move towards dealing with the city image as a replica of global cities like Chicago, Hong Kong and New York' skylines. The second was in building international projects particularly museums to gain the world recognition. The case of Abu Dhabi's cluster of cultural projects on Saadiyat Island including the new Louvre is worth mentioning in this context. The third cycle is related to the notion of hosting global events as Dubai did managing to be selected for hosting the world Expo 2020 or Qatar' success to win the bid for hosting the 2022 FIFA World cup. The three cycles were a result of the unprecedented financial revenuers generated from the oil and gas resources. As these cities compete with each other, aiming to highlight their unique offerings and attempting to clearly distinguish themselves from other cities, they have chosen to rely on place-branding as a tool. The staging of events of international importance (such as Formula One Races in Abu Dhabi, upcoming World Expo 2020 at Dubai and prospective 2022 FIFA World Cup at Qatar), the emphasis awarded to star-architecture and the emergence of strongly themed mega-projects characterize such development. Thus city-positioning and place-branding begin to assume the status of urban development models (Mishra, 2016). All the Gulf cities are in the process of diversifying their economic base, with the vision of 
transitioning to a sustainable post-oil future, they are positioning themselves as places to visit, work and live. Place-branding has emerged as a significant trend across the Gulf cities in the construction of this image and consequently in the production of places. With oil resources running out, a focus on the post-oil era is a priority. Assessing the pace of urban development in contemporary Gulf cities revealed number of critical issues (Wippel, 2014). On one hand, the speed of development has social cost, negative relation with the past and the claim for identity loss. On the other hand, such rapid developments contributed to economic diversification, cultural tourism and city branding. The overarching issue is exploring critically the ways in which the Gulf States prepare themselves for the post-oil era, by diversification of their assets, boosting real estate sector, and creating a knowledge economy.

\section{The Narrative of Doha, Qatar: An Emerging Urban Brand}

\subsection{A City as a Vibrant Hub}

In the last decade, Qatar has transformed itself into a major hub for numerous economic and cultural activities. Hosting several top-level sporting tournaments, culminating in the successful FIFA World Cup 2022 bid, is contributing in establishing Doha as an emerging urban and development brand within the Gulf and Middle Eastern contexts. Whether to counter regional economic competitors or to further tie Qatar to the economies of the world's leading countries, this brand is designed innovatively to counter a range of security concerns; in short, Qatar is diversifying its dependencies (Roberts 2015; Alraouf, 2016). Furthermore, Qatar has become attractive as a place for foreign knowledge workers and the creative class. This is the class of people who are moving around the world and attracted to the quality of urban environments which maintain their creative and intellectual outputs (Florida, 2002; 2005). Qatar's national vision for the year 2030 consists of basic foundations focused on the necessity of continuous social development in order to achieve a fair and safe society based on upholding human values and social welfare and aims to maintain and improve its economic standards in order to further strengthen its national economy and remain competitive, while continuing to secure and satisfy the needs of its citizens (QNV 2030). Maintaining the current growth of its urban population and fostering quality of life is seen as critical to the future development of the country, as indicated in the national development strategy 2011-2016 (QSDP, 2011). Such vision is supporting the way by which the new generation of knowledge workers decide on where to live as Florida argues (Florida, 2008). Qatar's economy has experienced three transformations.

\subsection{Place-branding and Place-making}

As place-branding aims at addressing the strategic goal of creating cities which attract residents, tourists, investments and workforces, it attempts to create and promote a specifically designed 'sense of place' (Lang 2011), thus becoming closely integrated with place-making. In addition to the immediate requirement of attracting the global spotlight, it aims at creating a vibrant public realm, considered an important indicator of livable cities. Interest in the public realm has reached high political levels and is evident through documents such as the Public Realm Design Manual (UPC, 2010.). Another point of convergence for both place-making and place-branding is their role in serving the sustainability agenda by addressing the economic, environmental and socials aspects. These 
interdependencies of place-making and place-branding present an opportunity for placemaking to leverage on branding efforts while also contributing towards it. However, despite the commonalities in these aims, there is an existing gap in the research which explores their relationship, particularly the influence of place-branding on the public realm. Reviewing this gap in research, Bani Hashim, (Forthcoming 2016) discusses the need for planners and designers to understand how place-branding manifests itself in physical and social environments, the 'place' component and the influence of branding on urban form and 'sense of place'. She elaborates that there is a gap in research on studies which examine the effect of place-branding on the place itself. This research aims to contribute towards filling this gap. With reference to the Gulf cities, place-branding has often implied new developments. Backed by a strong political will, the large-scale planning and mega-projects have been unencumbered by issues of renewal or relocation. This accelerated speed of their realization has meant that checks, balances and the possibility of participation and feedback from user are often excluded. These new projects may be looked as experiments requiring further examination. By focusing on how public space is used, the research attempts to establish a connection between built environment professionals and the end users and enrich the availability of studies which examine the relation between place-branding and the place itself.

\subsection{Theoretical Thoughts}

Several researchers discuss the shared aims in branding and architecture-urbanism as a political tool, a promotional medium and an identity definer (Kavaratzis 2009, Klingmann 2007). Muratovski (2012) explores the role of architecture and integrated design in citybranding, while also discussing notions of territory and iconicity. Place-branding with its manifestation as mega-projects, creation of landmarks and involvement of 'starchitects' affects the consumer experience and has been criticized for failing to craft a unique identity through the standardized 'brandscapes' (Klingmann 2007). Castello (2010) reflects on the complementary nature between place-making and place-marketing with the latter having become a modern instrument and constant complement to the process of creating new urban places. Many urbanists, through their research, have highlighted the importance of the human dimension in urbanism (Jacobs 1961, Gehl 2013) and offered insights into systematically studying environmental behaviour (Zeisel 2006) through international studies in public life (Whyte 1980, Gehl 2013, Mehta, 2007, 2009).

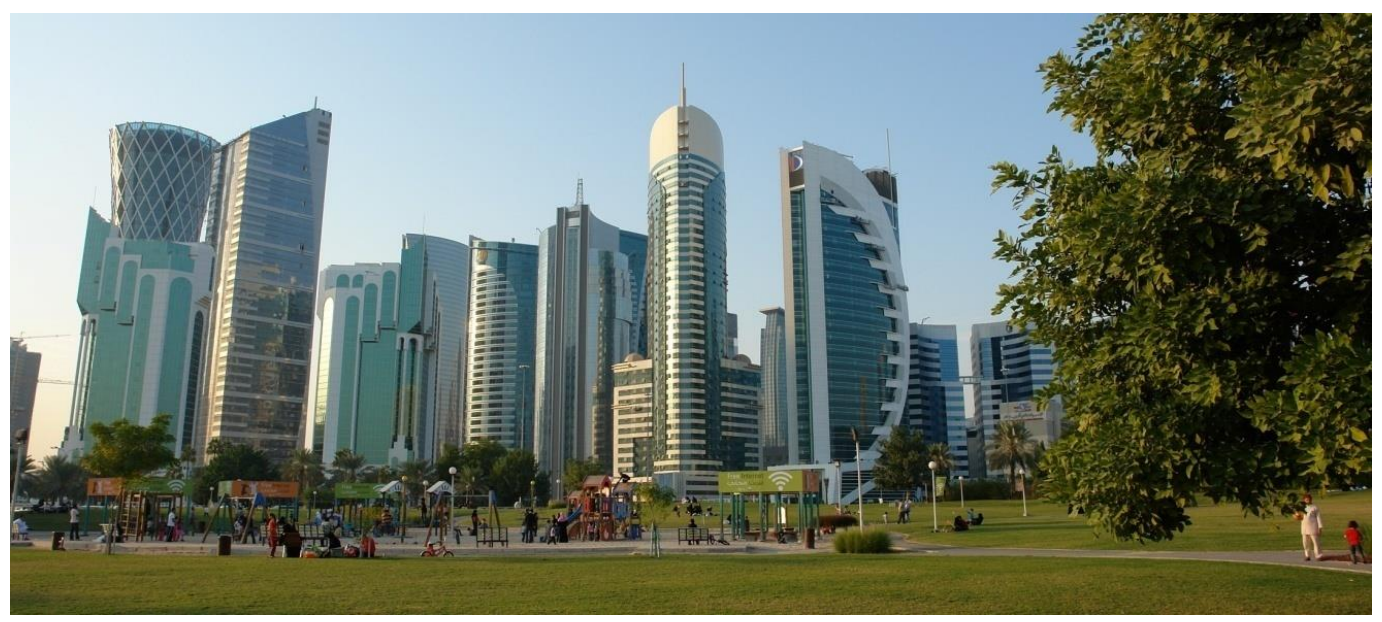

Figure 2 The City's Contemporary Image 


\section{Suggested Concepts in urban and architectural Branding and marketing}

\subsection{Branding the city in the Post Globalization Era}

Indeed, creating a marketing personality for the city is an important concept that is often difficult to comprehend and interpret. Although it is a new concept, it has become the inevitable application of any city seeking growth and development in the contemporary world. Cities can also generate visual impressions that distinguish them from other cities by focusing on what they own and by planning to add new dimensions to their architectural and urban personality. The most contemporary theoretical theses that established a new era in interpreting the success of the cities, most notably the development thought formulated by the prominent researcher in the field of development studies Richard Florida. He founded a new era in the history of cities and the methods of planning and growth techniques. His intellectual contribution began with his book entitled "The Rise of the Creative Class" published in 2002 in which he addressed a new proposal to understand the fabric of the human society in the post-globalization era. Indeed, the world has surpassed that era and has become the continuation of ideas, markets, investments and the fusion of spatial boundaries. Geography is a dominant feature in which all developed societies, as well as communities seeking a better life.

In his next book, "Who's Your city?", Florida established the importance of place and how our choices of where to live affect our creative contributions. This proposal is closely related to the emergence of the so-called global citizen, or the knowledge workers. Additionally, it calls for a new sector of creative, innovative thinking minds that depend on their contribution to the knowledge sector or rather the areas of knowledge economy as a basis for their professional success. Such phenomena have pushed Florida to warn that the escape of the creative and cultured class of the city leads to its death according to its expression. This new sector of the human community formulates a new conception of the relationship with the geography of the place. It goes beyond the emotional dimensions that make some cling to their first place and make their ability to move limited and restricted by a certain geographical scope may sometimes not exceed several kilometres from his birthplace and origin as it is with large segments of Arab society, this new category of human society is highly dynamic. With its aspirations and hopes in the place of our country and space to unleash its innovative and innovative capabilities in the era of the knowledge and creative economy based on the value Ideas. Hence, the emergence of this category contributed to the development of a new direction in the planning and Constructional thought presented by the literature under the title of the urban competitiveness which stimulated all cities of the world seeking a privileged position on the map of the twenty-first century.

Since the advent of the concept of urban competitiveness, the mechanisms and methods adopted by the cities have emerged, most importantly the city marketing policies to contribute to the consolidation of their presence on a competing world stage. The most radical in the city's marketing policies is to be transformed into a brand or a commercial figure that influences people's consciousness and converts them from their admirers to 
advocates and advocates and is responsible for convincing others to create the best intellectual and imaginary impressions of the city. The formulation of a distinctive marketing personality of the city has symbolic value such as international brands, is a process that develops in several stages the first is the awareness of the city and draw attention to it and to believe in it and defend its position and value with enthusiasm we clearly monitor it in the cases of cities such as Paris, London and New York. Therefore, the Imperative questions are; how does the city creates its own brand and distinguished character? How the city market itself? It is no longer surprising that cities are using global marketing experts to formulate a city's branding and marketing strategy. In the following section, suggested strategies that can achieve the city's vision of its distinctive personality, are articulated.

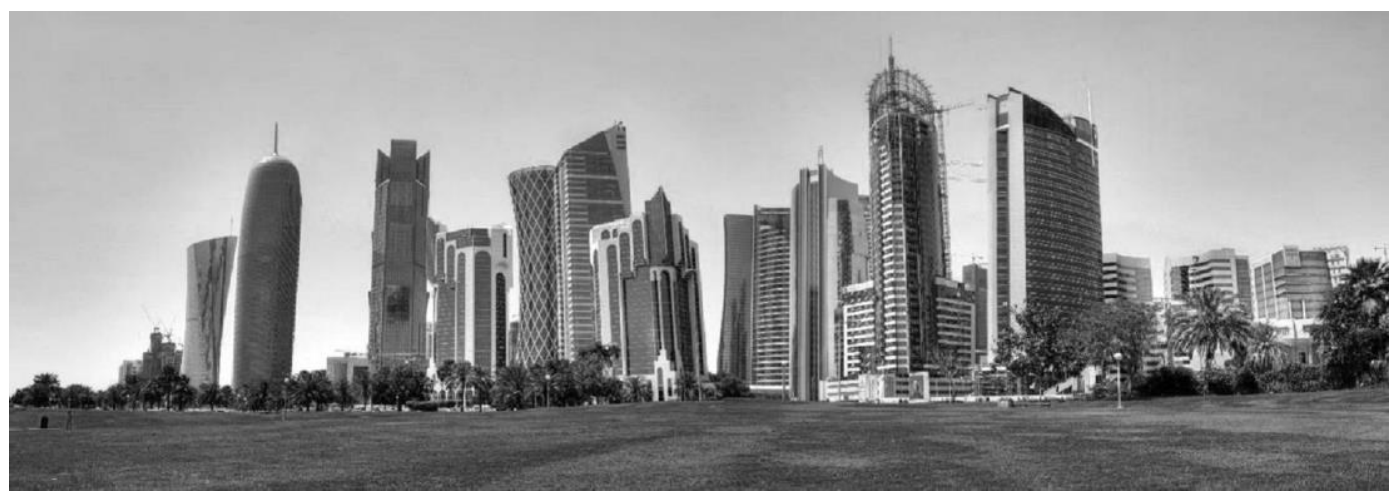

Figure 3 The City's in the Era of Globalization

\subsection{Suggested Policies}

First: The ability to attract important events and actors with a global impact.

The modern city is no longer a dialogue of its population but extends to the interaction of the world in the era of communication revolution and the unprecedented ability to communicate and an important part of this communication is to move to the stage of polarization of the other through the ability to host artistic events, sports, cultural and economic deepening the idea of communicating with the other The desire to open up to the world emphasizes the global value of the city and reformulates its urbanism and architecture so that it can play this global role. 


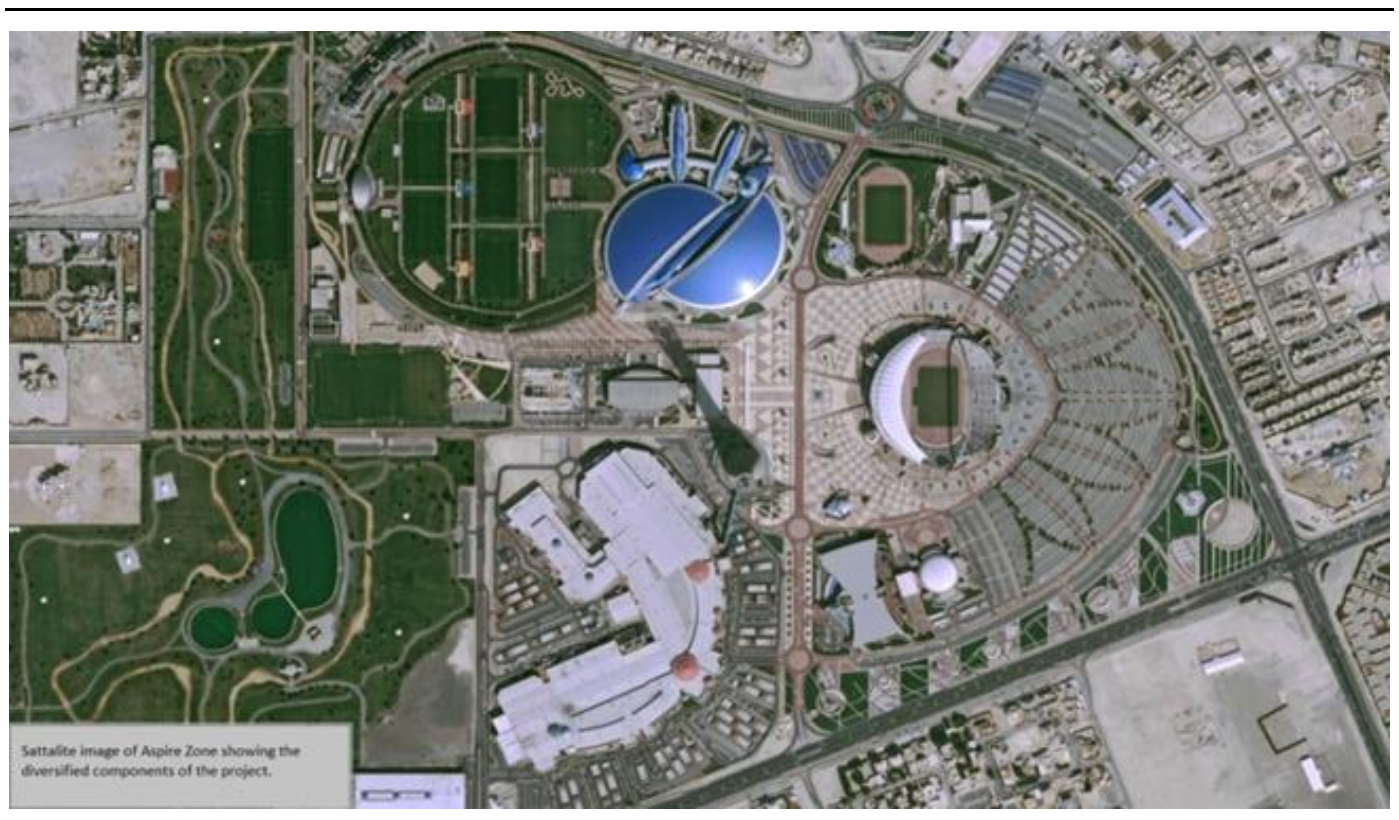

Figure 4 A Satellite map of the Aspire Zone with all its main components including the sports facilities, the park, the mall, and related community facilities (Source: Courtesy of Urban planning section, Doha).

Second: Employ the architectural and Urban Assets.

The city's valuable architectural and physical heritage is an essential tool to market it if it is activated by preserving it first and then by offering new experiences to interact with the place by re-employing this heritage, as did Arab cities such as Damascus, Medina, Aleppo, Syria, Fez and Marrakech, Morocco. Equally important, what the city will have in its future projects plays a vital role in marketing it. Indeed, the exciting and creative architecture has become one of the most important urban marketing tools of the city. The Guggenheim Museum in the Spanish city of Bilbao, designed by the American architect Frank Geary, was the beginning of the spark of a new methodology that would revive the city and market it through a single building that offers a visual and aesthetic breakthrough in the city's urbanism. Today, the Arab cities have recognized this standard and are competing to attract the stars of the architecture to leave their fingerprints on their architectural map, and their touches are approaching the east after their creativity is limited to the western cities and their flow to the Middle East Square, beginning with Frank Jerry, Jean Nouvel, Tado Ando and Michael. Graves and IBM to Zaha Hadid and they all formulate their creations in Manama, Kuwait, Dubai, Abu Dhabi, Cairo, Damascus and Doha. Any city's architectural and urban heritage has a great value and is an essential tool for its marketing and branding. Heritage when kept well maintained can be activated to provide new experiences of interacting with the place through the introduction of new uses and activities ${ }^{i i}$. 


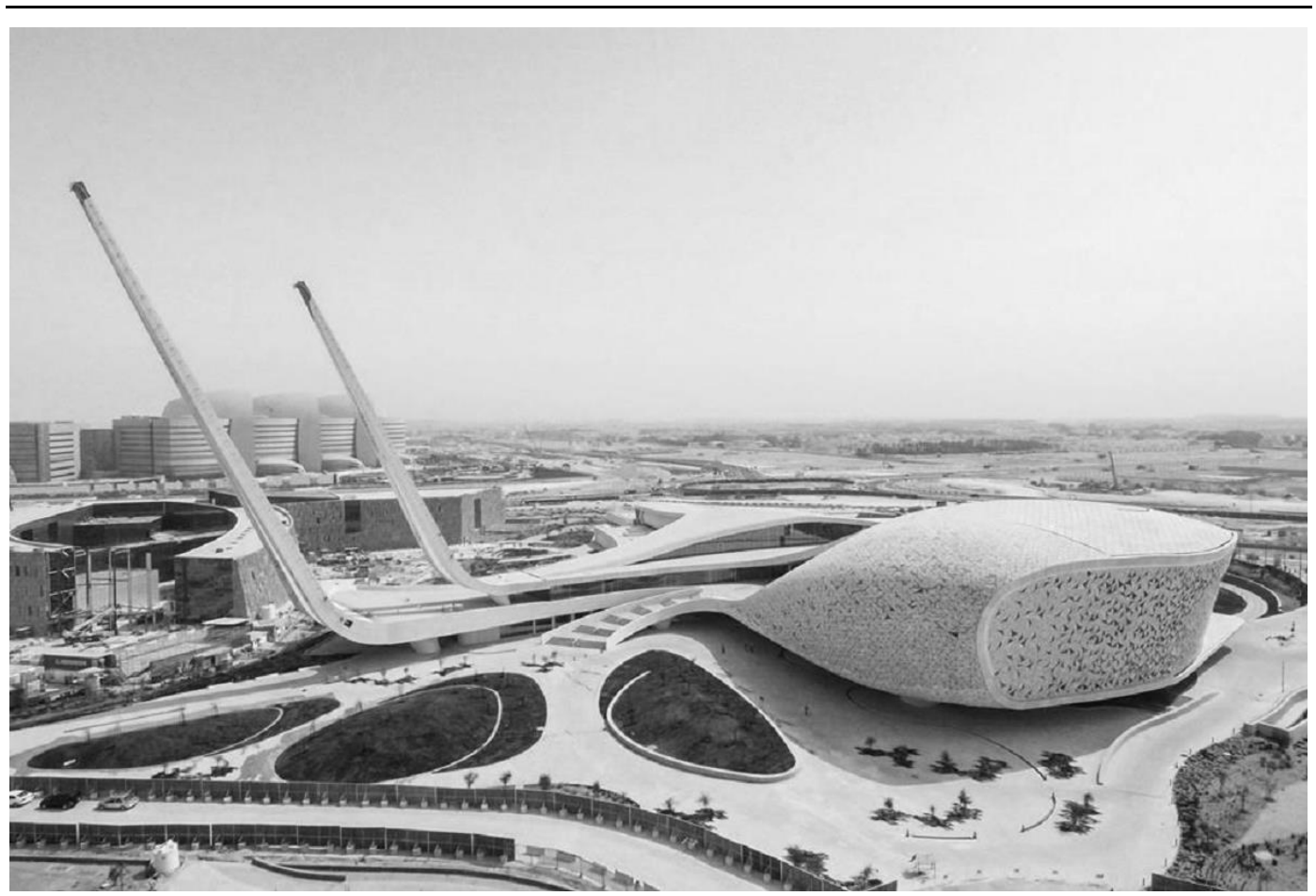

Figure 5 The Role of Creative Architectural Interventions in Constructing the City's Brand

Third: Search for the city's natural, cultural, and humanitarian distinctiveness.

The city may be distinguished from mountains surrounded by or rivers that penetrate it or from the presence of high-level cultural elements, especially museums of different types and may be new shopping environments that go beyond traditional ideas or through the ability of the human community in the city to celebrate and the existence of public spaces And the life that the city provides through these spaces, especially in terms of celebrations, festivals and carnivals, whether cultural, artistic, popular or spiritual religious. Even if what distinguishes the city is the style of movement, such as in the Italian city of Venice with its famous Venetian boats or the horse-drawn wagon in the centre of the Austrian city of Vienna or the famous red buses touring the English capital of London. Important is the ability to show this distinction in the scene of crafting the character of the city and its marketing.

Fourth: The formulation of a Brand for the city with historical tributaries and future ambitions.

The goal is to be a conscious monitor of the personality of the city that participates in its planning so that the process of confirming the character of the city and renewing it and installing it in a new form is a continuous dynamic process supported by architectural and constructional projects and patterns of movement and the excellence and distribution of uses Build on the humanitarian and environmental reference to development so that the city becomes a city for all and a model for sustainable development that calls for the rights and aspirations of future generations. 


\section{The state of Doha: the capital of culture, knowledge, sports and Oasis of Peace}

For a city to create its own marketing personality, it must begin with a sincere assessment of its advantages, as well as shortcomings and obstacles, and then try to maximize those features. As Gumathan Gabay argues (2009), the city's marketing is not just a painted slogan, but in the small, subtle details that make the streets Clean, it is in the deep details that make the city's residents ambassadors and proud to belong to it, and then the positive messages move to the actual or digital visitors of the city through the new multimedia. Producing a positive impression is an essential act for cities that want to advertise themselves as chosen destinations for people whether to live, work, entertain or visit. Hence, media outlets are an important area for the city's marketing, and the city has been used in media of all kinds as a sign of the strength of the city and its importance to the European cities ladder in the famous study prepared by Saffron consulting company in 2008 to evaluate 72 European towns. The city's marketing strategy must also be multidimensional and dynamic, responding to cultural, economic and developmental developments. Are we dreaming of travelling to Arab cities; Doha, Cairo, Kuwait, Damascus, Amman, Manama, Tunis, Baghdad, Beirut, and others, is the dream of new generations of the global human community, with unique global values that have a marketing value that makes people scramble to explore or work. Or choose a new home as they all yearn to the fragrant streets, squares and architecture of Paris, London, Vienna, Geneva and New York.

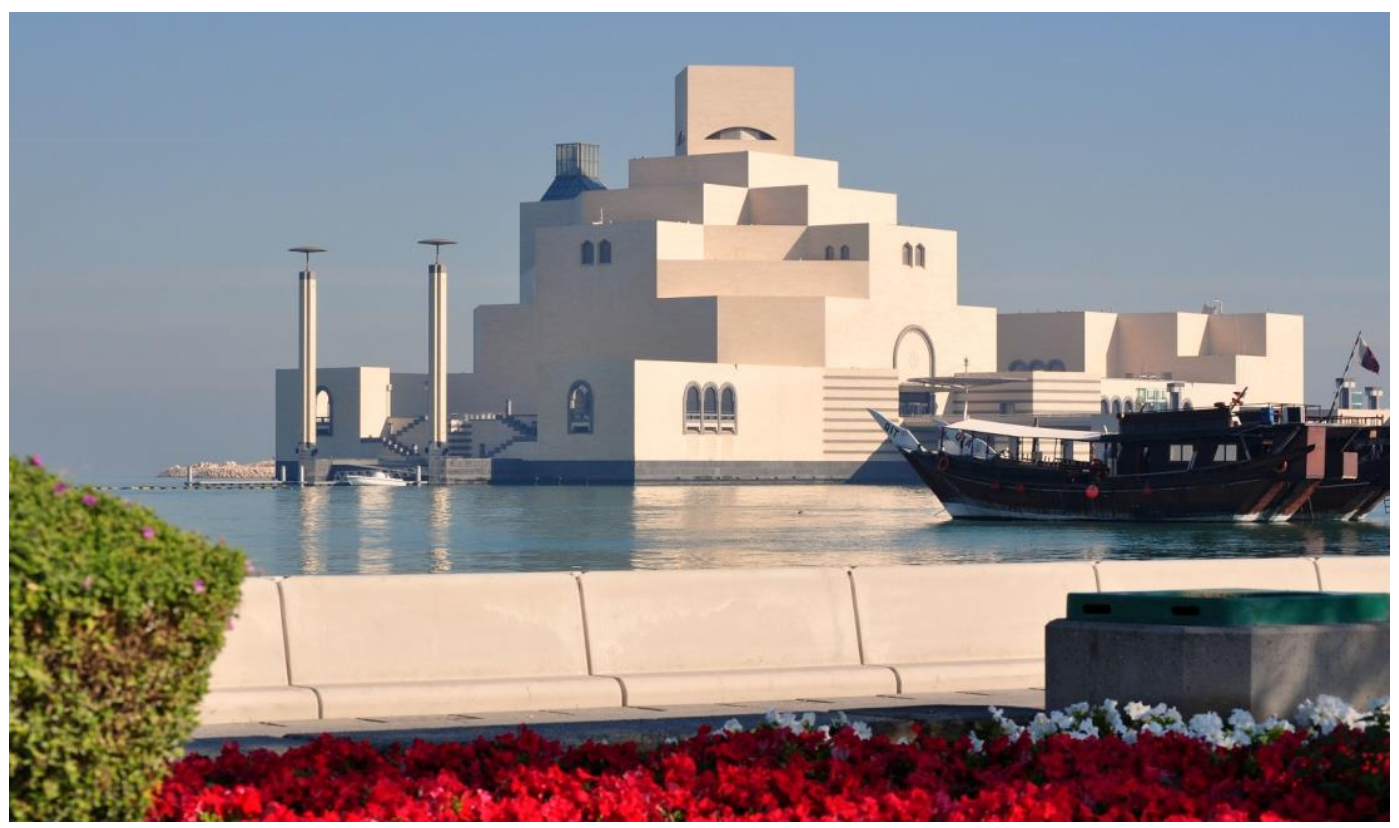

Figure 6 Museums designed by Signature Architects are Enhancing the City Branding, the Case of Museum of Islamic Art, Doha.

Interestingly, in the case of the Qatari capital city of Doha, it has used all the strategies available to market the city locally, regionally and globally, and its class consciously and with time frames that gave the city's reputation and its marketing personality a big and global place but at the same time sustainable and continuous it is not a boom or glow that quickly 
switches off. At the level of the polarization of events, Doha was transformed into a world sports capital by hosting the 2006 Asian Games, Tennis championships, horses, golf, volleyball, and world athletics, as well as its contribution to the 2022 World Cup, and the city hosts dozens of international conferences such as Conference of International Chambers of Commerce and consummate political reconciliation. With regard to the use of architectural and urban assets in the historical and contemporary areas, Doha has paid special attention to its architectural and urban heritage and the revival of Souq Waqif, a unique Gulf-wide experience that reflects this trend and has used contemporary architecture to change the line of the city sky and develop its personality As an emerging global polarization hub, Doha has confirmed its own character as a city with a balanced balance between maintaining historical tributaries and developing visions and future ambitions that change the whole city and push it to the world stage. Doha was also concerned with the environment and the importance of preserving it and then enriching the cultural experience of the city through the establishment of various cultural, cognitive and academic projects and interacting with the community of citizens and residents alike, such as the Islamic Museum, the cultural quarter and the educational city, and finally the successful city It is a city that addresses the human being and dialogue with his mind and his emotions and his requirements this latter element, as is evident in Qatar's vision 2030, will make Doha a complete model if all the tissues will be unprecedented and the dream of the Arabs is realized in a city that the whole world dreams of.

\section{Strategies for Positive City Branding: The Case of Doha}

\section{Doha as a Sports Capital of the Middle East.}

One of the routs to promote tourism in Qatar which will be interrogated in the chapter is turning Doha, the Capital city into a regional and international sports hub. The city was able to host global sports events capital like the 2006 Asian Games, ATP and WTA tennis tournaments, Global Equestrian Tours, golf, volleyball and World Cup in Track and field. In addition to winning the bid for hosting the 2022 FIFA World Cup. The Department of urban planning and urban plan in full coordination with the country's Olympic Committee and the World Cup Organizing Committee to help keep the country cities livable cities attract highprofile sporting events. Urban planning contributes to locate required services especially hotels, playgrounds, markets in addition to the public transport network for high level includes Metro and bus rapid transit buses in addition to pedestrian and bicycle traffic networks.

One of the most prominent projects to prepare Qatar to cement its position as the sports capital of the Middle East is The Aspire Zone: A New Concept for an Urban Community Park where Sports, Retail and Cultural Hub is created. The Aspire Zone, also known as Doha Sports City is a 250-hectare $(2.5 \mathrm{~km} 2)$ sporting complex located in Al Waab district. The project is a complete mega development centered on the concept of branding Qatar as the sports capital of the Gulf. It was established as an international sports destination in 2003. The complex contains several states of the art sports venues, mostly constructed in preparation for the 2006 Asian Games. To complement what was perceived as a newly constructed vibrant urban center in Doha, different facilities and supporting amenities were added gradually. In 2004 Aspire Academy, an educational center for the development of sporting champions was opened. The zone embraces Khalifa International Stadium which 
was first built in 1976 and has long been the vibrant center of the country's sporting tradition. As the hosting nation of the World Cup 2022, the Stadium was subjected to a holistic renovation to be compliant with FIFA's stadium requirements. Attached to the stadium is the Qatar Olympic and Sports Museum which will be promoting the positive value of sports. The other sports facilities include Aspire Dome which is credited as the world's largest indoor multi-purpose court and Hamad Aquatic Center. To guarantee the holistic role of the sports zone, the project includes Aspetar, a specialized sports medicine hospital.

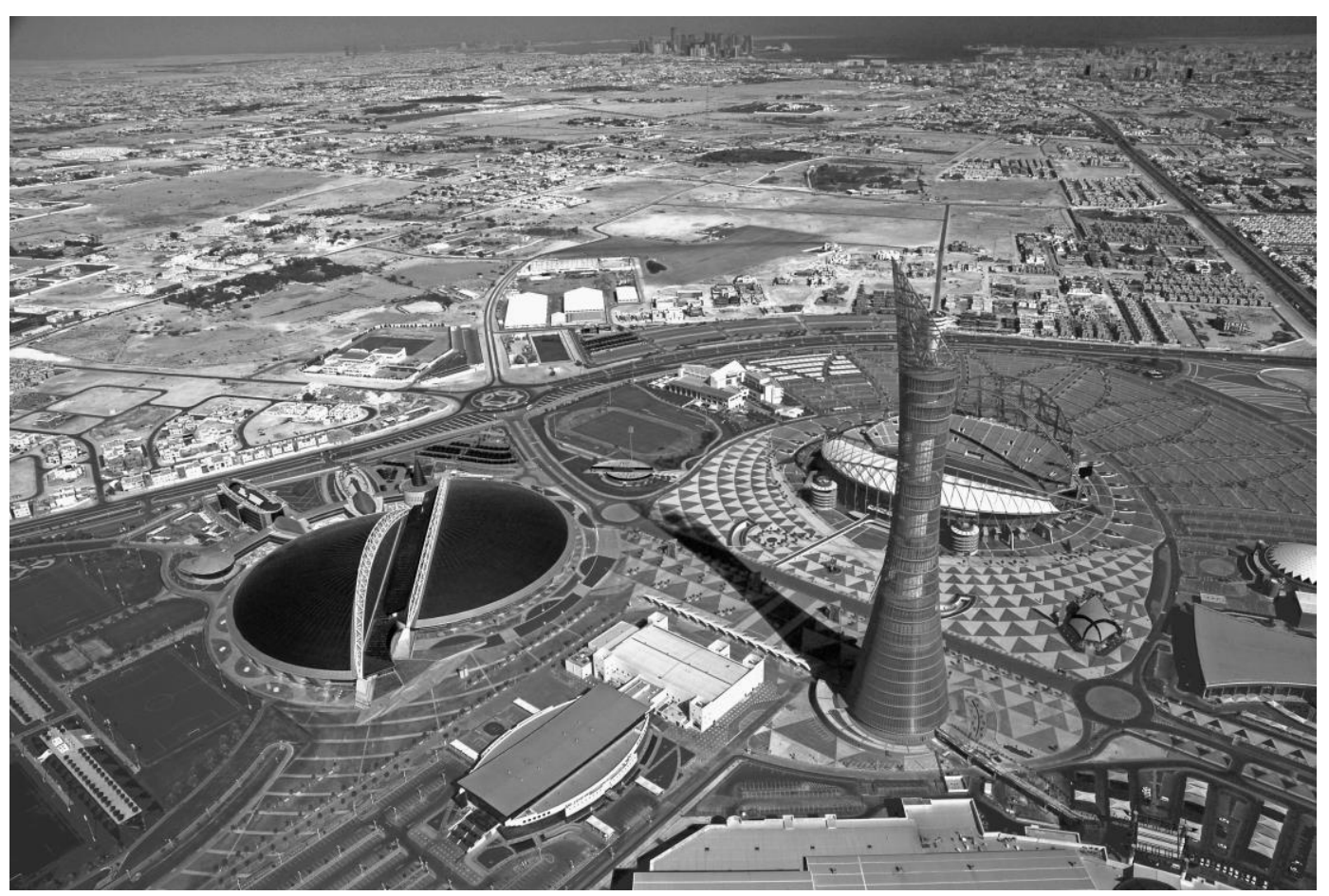

Figure 7 Establishing the Needed Facilities to Allow the City to act as the Sports Hub of the Middle East

\section{Branding Qatar via Doha's Emerging Knowledge-based Urbanism}

Architecture, urbanism and planning are used, as will be explained in the coming sections, to prepare the country for the post-carbon era and establish a model which transcends the Dubai's dominance as a reference for development in the gulf. Dohaization is consciously perceived as a process to brand Doha in a balanced manner focused on the image and the content (Alraouf, 2016). Such preparation includes creating the environment which would attract knowledge workers and creative people from around the world to settle in Qatar and contribute in its new economical and development paradigm. On a planning level, the new blueprint for the urban development of Qatar titled "Qatar National Development Framework (QNDF)" is the outcome of Qatar's urban planning department and its focus group envisioning Qatar National Master Plan (QNMP). The main pillars of the framework suggest a new form of urbanism for Qatar articulated around planning for sustainable growth, compacted settlements, transit oriented urban development, walkability, mixed use urban centers and positive public realm. Such new planning principles aim at transforming Qatari cities and municipalities into people-friendly places and spaces and create the attractive environment which speaks to knowledge and creative workers considering Doha 
and other Qatari cities as their new homes. For instance, enhancing walkability within the West Bay development is considered as a catalyst to transform the city business district from a composition of isolated towers and skyscrapers into a network of activities which would enhance social integration, walkability, public real and urban connectivity.

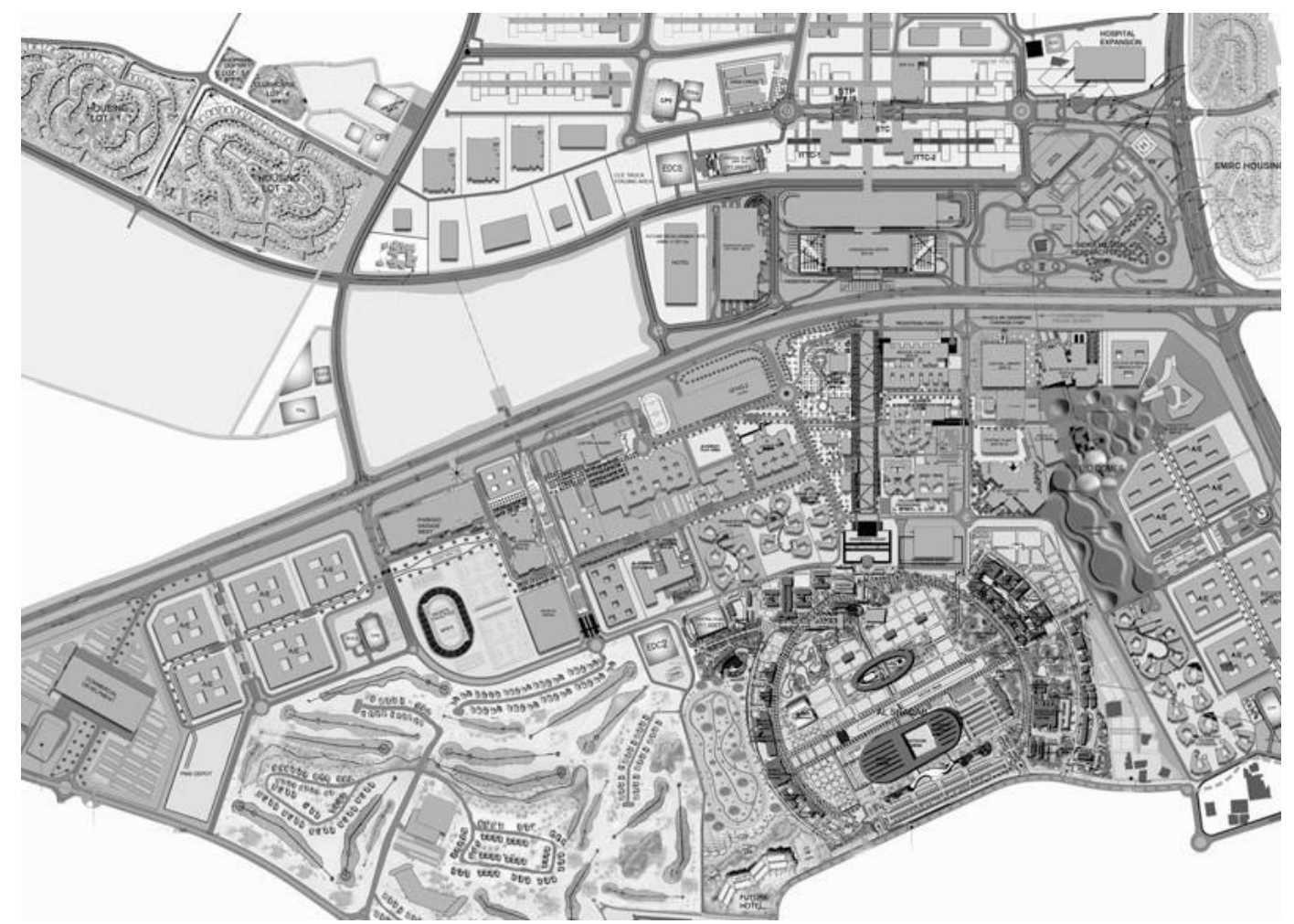

Figure 8 The Master Plan of Education City in the Heart of Doha as a Representation of KBUD

\section{Cultural Tourism in Qatar: From Marginalized to Centralized Economic Pillar}

One of the most important features about contemporary tourism is its ability to engage global visitors in memorable and sometimes transformational experiences. The classical interpretation of tourism as an opportunity to merely see local or global landmarks coupled with some sensory interactions with food and entertainments was profoundly transcended by new concepts and approaches. Qatar acknowledges that it is not a country with distinguished natural scenes or unique flora and fauna. Hence, more investment is geared towards cultural tourism using the cultural infrastructure of the country and its capital city; Doha. Hence, the fundamental question while shaping the tourism national strategy was can cultural tourism act as a driving force towards economic diversification. While Qatar critically acknowledges the vitality of considering tourism as one of its main pillars for economic diversification, yet, the State exhibits clearly its unwillingness to compromise religious, cultural, and social values. Such a clear determination resulted in shaping a strategy for tourism development which transcends the typical entertainment-based tourism. So, the challenge was creating a balanced strategy for tourism development in Qatar. Yet, even as Qatar sought to attract visitors, its tourism policy was carefully and strategically crafted to preserve local culture and prevent environmental degradation. Qatar should pursue a highvalue, low-impact tourism. The small State should maintain a strict sustainable tourism 
policy. Tourism if seen as a significant part of Qatar's economy, all policies and regulations should guarantee and ensure that its natural and cultural resources will be protected and stay attractive to tourists for decades to come. Published in 2014, the Qatar National Tourism Strategy (QNTS) sets out the plan for the development of Qatar's tourism industry over the next few years ${ }^{1}$. In qualitative terms, QNTSS spells out the focus of future tourism development. This will be based on developing a diversified, premium product that attracts families and travelers looking for new cultural experiences.

Qatar as echoed in its vision (QV2030) and tourism development strategy (QTS, 2014), considered the local values and traditions as core components of its identity and character. Therefore, the analysis of the current efforts in Qatar to promote an era of tourism development reveals a number of indicating trends and issues. In the following sections, a discussion is conducted to reveal the alternative approach adopted by Qatar to move beyond the emphasize on entertainment-based tourism which might in some of its components compromise the national values and traditions. Analyzing the Qatar tourism strategy, urban development framework and the State's economic diversification policies substantiates the State's unique approach towards balanced tourism development.

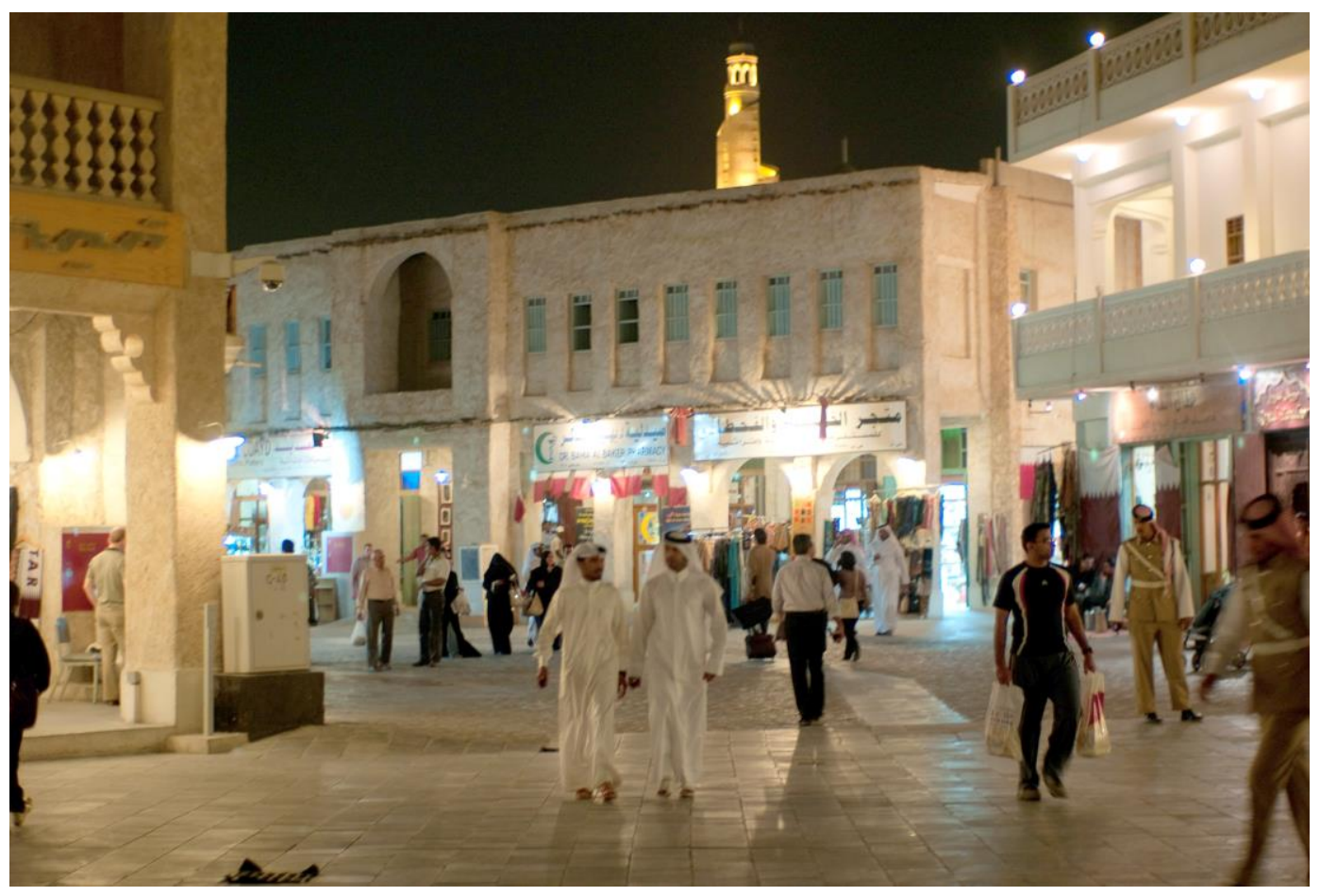

Figure 9 The Heritage Areas as Centers to promote Cultural Tourism

\footnotetext{
1 The Establishment of Qatar Tourism Authority: Realizing the fact that tourism is vital in the post-oil economy, Qatar Tourism Authority (QTA) was established in 2011 and changes to National Tourism Council in 2018 after HH the Amir Sheikh Tamim bin Hamad Al Thani issued the Amiri Decision No.74 of 2018.
} 


\section{Conclusions and recommendations}

This research first provided a background on place-branding, its origins and importance in shaping the public realm of Doha. The new trends in urban planning implemented in Qatar enrich cultural experience in the country, especially the capital city Doha. A number of cultural, academic projects are established to create an interactive knowledge platform with the community of citizens and residents alike. At the same time such projects attract specific quality of tourists, knowledge workers, short and long-term researchers and global travelers. Museum of Islamic Art (MIA), Education City, The Cultural District (Katara) and Qatar National Museums are part of such widely implemented interventions within the fabric of Doha. Such projects have been coordinated and fully integrated with the city to promote cultural tourism in the era of knowledge economy and knowledge-based urban development. The main conclusion of the chapter is that, although tourism development may provide a viable economic solution to some of the major socio-economic problems currently facing the Qatar but as a more holistic approach, knowledge-based urban development should be perceived as the most appropriate answer for the quest to overpass the oil economy era and moving vigorously towards post-oil one. A large part of the motivation behind the KBUD projects in Qatar is clearly the desire to establish the State as both a tourist destination and as an ideal place where knowledge workers might be prepared to relocate. Hence, Qatar's balanced approach to tourism development is becoming a crucial component in its overall strategy to be a balanced representations of knowledge-based urban development State open for a diversity of people composing an interesting tapestry of just, open, and knowledge-based urbanity. The strategic objectives of megaprojects in Qatar are achieved via branding the State as a new destination for cultural events, sports international competitions. It is also achieved via establishing Qatar's new identity as a context for knowledge and creativity attracting knowledge workers from all over the globe. While it is important to note here that Qatar is not only focusing on providing a new milestone in hosting mega sports events but more importantly, using the event as a catalyst for future development and progress. Qatar and as provided in the study, is fully aware of the previous negatives experiences of similar countries that faced substantial failure in transforming hosting the event into an opportunity for development and future legacy. The study shows that the main requirements of Hosting the 2022 FIFA world cup are perceived by the leadership and executive authorities in Qatar as needed for the country not only for the event. Such major strategic difference would make Qatar a winner not only economically but socially, culturally and better prepared for a post-Carbon future.

\section{References}

Abdullah, Mohamed and Atar, Maher. 2006. Souq Waqif. (Doha: Al Diwan Al Amiri).

Al Buainain, F. 1999, Urbanisation in Qatar: A Study of the Residential and Commercial Land Development in Doha City, 1970 -1997, PhD Thesis, University of Salford, Salford. 
Al-Kholaifi, Mohammad J., 2003. The Traditional Architecture in Qatar (In Arabic). Doha: National Council for Culture, Arts and Heritage.

Alraouf, Ali. 2017. Interrogating Qatar's Urbanity as a Catalyst for Building Knowledge-Based Societies and Economies. In Bertelsen, Rasmus Gjedss; Noori, Neema; Rickli, JeanMarc (eds.) Strategies Of Knowledge Transfer For Economic Diversification In The Arab States Of The Gulf. Pp: 53 -66. London: Gerlach Press.

Alraouf, Ali. 2016A. "Dohaization": An Emerging Interface between Knowledge, Creativity, and Gulf Urbanity. Pp.: 47-68. In Katodrytis, George and Syed, Sharmeen. Gulf Cities as Interfaces. Cambridge: Gulf Research Centre Cambridge.

Alraouf, Ali. 2016B. Museums as a Catalyst for a New Urban and Cultural Identity in Qatar Interrogating the Case of Museum of Islamic Art. In Museums in Arabia: Transnational Practices and Regional Processes.). Exell, Karen and Wakefield, Sarina (eds.) (Ashgate: UK, 2016).

Alraouf, A. 2016. One Nation, One Myth and Two Museums Heritage, Architecture and Culture as Tools for Assembling Identity in Qatar. Representing the Nation: Heritage, Museums, National Narratives, and Identity in the Arab Gulf States, Publisher: Routledge, Editors: Pamela Erskine-Loftus, pp.79- 94.

Alraouf, Ali. 2012. A Tale of Two Souqs. In or Out of Place: The Paradox of Gulf Urban Diversity. Open House International Journal. Volume 37, Issue No. 2, June 2012. Pp:72-81.

Alraouf, Ali. 2008. Emerging Middle Eastern knowledge cities: the unfolding story. In Yigitcaular, T., and Koray, V., eds. Knowledge Based Urban Development: Planning and Application in the Information Era. IGI Global Publishing.

AlSayyad, Nezar (ed.). 2001. Consuming Tradition, Manufacturing Heritage: Global Norms and Urban Forms in the Age of Tourism. London: Routledge.

Castello, L. 2010. Ethnoscapes: Rethinking the meaning of Place: Conceiving Place in Architecture - Urbanism. Routledge.

Cooke, M. 2014. Tribal Modern: Branding New Nations in the Arab Gulf. University of California Press.

Dinnie, Keith. 2011. City Branding: Theory and Cases. Palgrave Macmillan.

Fromherz, A., 2012. Qatar: a Modern History. Washington, D.C.: Georgetown University Press.

Kamrava, Mehran. 2013. Qatar: Small State, Big Politics. New York: Cornell University Press.

General Secretariat for Development Planning. 2008. Qatar National Vision 2030. Doha: General Secretariat for Development Planning.

Evans, G. 2012. "Branding the City of Culture - The Death of Planning?" In Culture, Urbanism and Planning, 197 - 214. Ashgate.

Gehl, J. and Svarre, B. 2013. How To Study Public Life. Translated by K. Steenhard. Washington, DC: Island Press.

Gehl, J. 2013. Cities for People. Washington, DC: Island Press. 
Jacobs, J. 1961. The Death and Life of Great American Cities. New York: Random House.

Gray, Matthew. 2013. Qatar: Politics and the Challenges of Development. Boulder, CO: Lynne Rienner Publishers.

Kavaratzis, M. 2009. "Cities and their Brands: Lessons from corporate branding." Place Branding and Public diplomacy 5 (1): 26 - 37.

Jacobs, J. 1961. The Death and Life of Great American Cities. New York: Random House.

Kavaratzis, M. 2009. "Cities and their Brands: Lessons from corporate branding." Place Branding and Public diplomacy 5 (1): 26 - 37.

Miller, Rory. 2016. Desert Kingdoms to Global Powers: The Rise of the Arab Gulf. Yale University Press.

Mishra, Anamika. 2016. Places in The Making: Abu Dhabi's Evolving Public Realm in The Context of Place-Branding. Gulf Research Meeting GRM 2016, University of Cambridge, Cambridge, UK.

Muratovski, G. 2012. "The role of architecture and integrated design in city branding." Place Branding and Public Diplomacy 8 (3): 195 - 207.

Muratovski, G. 2012. "The role of architecture and integrated design in city branding." Place Branding and Public Diplomacy 8 (3): 195 - 207.

Roberts, David B. 2015. Qatar: Securing the Global Ambitions of a City-state. London: C Hurst \& Co Publishers Ltd.

Stephenson, Marcus L. and Al-Hamarneh, Ala. 2017. International Tourism Development and the Gulf Cooperation Council States: Challenges and Opportunities. London: Routledge.

Qatar National Development Framework (QNDF). 2016. The Ministry of Municipality and Environment.

Qatar National Vision 2030. 2008. General Secretariat for Development Planning. www.planning.gov.qa.

\footnotetext{
${ }^{\mathrm{i}}$ A more holistic understanding of the different strategies of city branding were discussed in City Branding: Theory and Cases (Dinnie, 2011).

ii Today, more than 12 sites in GCC countries are listed on the UNESCO list of world cultural heritage. Among them, the oasis of Al Ain, Historic Jeddah, Qal'at Al-Bahrain, Bahla Fort in Oman, and Al Zubarah Fort in Qatar.
} 